\title{
Interleukin-1 $\beta$ and 6-Induced Calcium Channel Current Modulation in MC3T3-E1 Osteoblast Cell Line
}

\author{
Hiroshi Kobayashi ${ }^{1}$, Takayuki Endoh ${ }^{2}$, Yushi Uchida ${ }^{3}$, Masakazu Tazaki ${ }^{4} \&$ Kenji Sueishi ${ }^{1}$ \\ ${ }^{1}$ Department of Orthodontics, Tokyo Dental College, 1-2-2 Masago, Mihama-ku, Chiba 261-8502, Japan \\ ${ }^{2}$ Department of Dental Hygiene, Faculty of HealthCare Sciences, Chiba Prefectural University of Health Sciences, \\ 2-10-1 Wakaba, Mihama-ku, Chiba 261-0014, Japan \\ ${ }^{3}$ Department of Orthodontics, Tokyo Dental College, 2-9-18 Misakicyou,Chiyoda-ku Tokyo 101-0061, Japan \\ ${ }^{4}$ Department of Physiology, Tokyo Dental College, Misakicyou,Chiyoda-ku Tokyo 101-0061, Japan \\ Correspondence: Takayuki Endoh, Department of Dental Hygiene, Faculty of HealthCare Sciences, Chiba \\ Prefectural University of Health Sciences, 2-10-1 Wakaba, Mihama-ku, Chiba 261-0014, Japan. E-mail: \\ takayuki.endoh@cpuhs.ac.jp
}

Received: November 18, 2014 Accepted: November 27, $2014 \quad$ Online Published: February 24, 2015

doi:10.5539/ijb.v7n2p68 URL: http://dx.doi.org/10.5539/ijb.v7n2p68

\begin{abstract}
Interleukin-1 $\beta$ (IL-1 $\beta$ ) and -6 (IL-6) are inflammatory cytokines that are involved in bone resorption under pathological conditions. The cytokines are also involved in bone remodeling under physiological conditions. Voltage sensitive $\mathrm{Ca}^{2+}$ channels (VSCCs) serve as crucial mediators of membrane excitability and many $\mathrm{Ca}^{2+}$-dependent functions such as growth of bone, regulate proliferation, differentiation, enzyme activity and gene expression. The effects of IL-1 $\beta$ and -6 on VSCCs in osteoblast cell line (MC3T3-E1) were investigated using patch-clamp recording. Our results showed that application of 50 pM-50 nM IL-1 $\beta$ facilitated VSCCs current $\left(\mathrm{I}_{\mathrm{Ca}}\right)$ carried by $\mathrm{Ba}^{2+}\left(\mathrm{I}_{\mathrm{Ba}}\right)$. Application of 50 pM-5 nM IL-6 facilitated $\mathrm{I}_{\mathrm{Ba}}$. In contrast, $50 \mathrm{nM}$ IL-6 inhibited $\mathrm{I}_{\mathrm{Ba}}$ in MC3T3-E1 cells. Treatment with MAPK inhibitor, PD98059, attenuated the 5 nM IL-6-induced facilitation of $\mathrm{I}_{\mathrm{Ba}}$. Treatment with STAT3 inhibitor, staffic, attenuated the $50 \mathrm{nM}$ IL-6-induced inhibition of $\mathrm{I}_{\mathrm{Ba}}$. Treatment with PD98059 also attenuated the $50 \mathrm{nM}$ IL-6-induced inhibition of $\mathrm{I}_{\mathrm{Ba}}$. These results suggest that 5 nM IL-6 facilitates VDCCs involving MAPK pathways. In addition, $50 \mathrm{nM}$ IL-6 inhibits VDCCs involving STAT3 and MAPK pathways in MC3T3-E1 cells.
\end{abstract}

Keywords: osteoblasts, Interleukin-1 $\beta$, Interleukin-6, calcium channels

\section{Introduction}

Interleukin-1 $\beta$ (IL-1 $\beta$ ), a potent inflammatory cytokine, is upregulated during inflammation mainly produced by activated monocytes and macrophages (Dinarello, 1997; Stylianou et al., 1998). It stimulates bone resorption in several cell types, including osteoblasts (Dinarello, 1988). IL-6 is a multifunctional cytokine which has diverse effects on bone metabolism. IL-6 has been shown to affect growth and differentiation in osteoblasts (Fang et al., 1991; Hughes et al., 1992; Ishimi et al., 1990).

Osteoblasts are known to play a major role in the bone formation. It is well accepted that osteoblasts express IL-1 $\beta$ and -6 receptors and therefore it plays an important role in bone remodeling (Blanchard et al., 2009; Shen et al., 1990).

Voltage sensitive $\mathrm{Ca}^{2+}$ channels (VSCCs) serve as crucial mediators of membrane excitability (Miller, 1987) and many $\mathrm{Ca}^{2+}$-dependent functions such as growth of bone (Duriez et al., 1993), regulate proliferation (Loza et al., 1994), differentiation (Wen et al., 2012), enzyme activity (Reuter 1983) and gene expression (Murphy et al., 1991). It also has been demonstrated that osteoblasts express VSCCs (Duncan et al., 1998; McDonald, 2004). Several reports demonstrated that IL-1 $\beta$ and -6 modulated VSCCs in neuronal cells (Ma et al., 2012; Zhou et al., 2006). However, the mechanism of IL-1 $\beta$ and -6 effects on VSCCs in osteoblasts has been extensively studied, but remains unclear and even controversial.

Consequently, in this study we investigated the effect of IL-1 $\beta$ and -6 on VSCCs in osteoblast cell line (MC3T3-E1). 


\section{Materials and Methods}

\subsection{Cell Culture}

Murine osteoblastic MC3T3-E1 cells were purchased from Summit Pharmaceuticals International Corporation (Tokyo, Japan). Cells were cultured at $37^{\circ} \mathrm{C}$ in a $5 \%(\mathrm{v} / \mathrm{v}) \mathrm{CO}_{2}$ atmosphere with $\alpha$-modified minimal essential medium ( $\alpha$-MEM; Gibco BRL, Grand Island, NY, U.S.A.). Unless otherwise specified, the medium contained $10 \%(\mathrm{v} / \mathrm{v})$ heat-inactivated fetal bovine serum, $100 \mathrm{U} / \mathrm{ml}$ penicillin and $100 \mathrm{mg} / \mathrm{ml}$ streptomycin. Cell culture medium was changed every 2-3 days. For patch-clamp experiments, cells were harvested using a $0.05 \%$ trypsin/0.02\% EDTA solution, when cells reached confluence. Cells were plated at very low density in $35 \mathrm{~mm}$ tissue culture dishes. Prior to recordings, the cells were washed at least three times with Krebs solution of the following composition (in $\mathrm{mM}$ ): $136 \mathrm{NaCl} ; 5 \mathrm{KCl} ; 2.5 \mathrm{CaCl}_{2} ; 0.5 \mathrm{MgCl}_{2} ; 10.9$ glucose; $11.9 \mathrm{NaHCO}_{3}$ and 1.1 $\mathrm{NaH}_{2} \mathrm{PO}_{4}$. The $\mathrm{pH}$ was 7.3-7.4. Cell culture reagents were purchased from Sigma (Tokyo, Japan). Our recordings were performed on 10-30 $\mu \mathrm{m}$ in diameter, since they were well suited for patch clamp recordings.

\subsection{Whole-Cell Patch-Clamp Recordings}

Voltage-clamp recordings were conducted using the whole-cell configuration of the patch-clamp technique (Hamill et al., 1981). Fabricated recording pipettes (2-3 M 2 ) were filled with the internal solution of the following composition (in $\mathrm{mM}$ ): $150 \mathrm{CsCl}$; 5 EGTA; 10 D-glucose and 10 HEPES. The $\mathrm{pH}$ was adjusted to 7.3 with $\mathrm{CsOH}$. After the formation of a giga seal, in order to record VSCCs current $\left(\mathrm{I}_{\mathrm{Ca}}\right)$ carried by $\mathrm{Ba}^{2+}\left(\mathrm{I}_{\mathrm{Ba}}\right)$, the extracellular solution was replaced from Krebs solution to a solution containing the following (in $\mathrm{mM}$ ): 115 $\mathrm{BaCl}_{2}$ and 20 HEPES. The $\mathrm{pH}$ was adjusted to 7.4 with tetraethylammonium hydroxide. Command voltage protocols were generated with a computer software pCLAMP version 10 (Axon Instruments, Union City, CA, U.S.A.) and transformed to an analogue signal using a DigiData1440A interface (Axon Instruments, Union City, CA, U.S.A.). The command pulses were applied to cells through an L/M-EPC7 amplifier (HEKA Elektronik, Lambrecht, Germany). The currents were recorded with the amplifier and a computer software pCLAMP10 acquisition system. Access resistance $(<15 \mathrm{M} \Omega)$ was determined by transient responses to voltage commands. L-1 $\beta$ and -6 were applied by perfusion pressure ejection from perfusion tubes with a tip diameter of $1 \mathrm{~mm}$ placed within $10 \mathrm{~mm}$ of the cell surface. Although the concentration of IL-1 $\beta$ and -6 actually seen by the cell is certainly lower than that contained in the stock solution, we applied the IL- $1 \beta$ and -6 using same perfusion system. L- $1 \beta$ and -6 were applied by perfusion pressure ejection from perfusion tubes with a tip diameter of $1 \mathrm{~mm}$ placed within $10 \mathrm{~mm}$ of the cell surface.

\subsection{Chemicals}

IL-1 $\beta$, IL-6 and PD98059 were purchased from Sigma (Tokyo, Japan). SQ22536 was purchased from Biomol Research Laboratories (Plymouth, PA, U.S.A.) 2-[1-(3-dimethylaminopropyl)-1H-indol-3-yl]-3-(1H-indol-3-yl)-maleimide (GF109203X) was purchased from Calbiochem (La Jolla, CA, U.S.A.). Staffic was purchased from Tocris (Bristol, U.K.). All drugs except GF109203X and staffic were dissolved in distilled water. GF109203X and Stattic were dissolved in DMSO. All drugs were diluted to the desired final concentration in the external solution just before use. The final concentration of DMSO was $<0.01 \%$, which had no effect on the $\mathrm{I}_{\mathrm{Ba}}$.

\subsection{Statistical Analysis}

All date analyses were performed using the pCLAMP10 acquisition system. Values in text and figures are expressed as mean \pm S.E.M. Statistical analysis was done using Student's $t$ test for comparisons between pairs of groups and one-way analysis of variance (ANOVA) followed by Dunnett's test. Probability (p) values of less than 0.05 were considered significant. Modulation of $\mathrm{I}_{\mathrm{Ba}}$ was calculated with the following formula:

Modulation of $\mathrm{I}_{\mathrm{Ba}}(\%)=$ After Application peak current $/$ Before Application peak current

Table 1. Statistical mean \pm S.E.M. at each concentration levels

\begin{tabular}{lllll}
\hline & IL-1 $\beta$ & $\mathrm{n}$ & $\mathrm{IL}-6$ & $\mathrm{n}$ \\
\hline $50 \mathrm{pM}$ & $22.8 \pm 4.0$ & 5 & $15.8 \pm 2.7$ & 10 \\
$500 \mathrm{pM}$ & $21.8 \pm 2.0$ & 6 & $23.0 \pm 4.5$ & 7 \\
$5 \mathrm{nM}$ & $34.1 \pm 3.9$ & 6 & $35.6 \pm 4.0$ & 8 \\
$50 \mathrm{nM}$ & $56.7 \pm 5.2$ & 3 & $-21.4 \pm 2.5$ & 3 \\
\hline
\end{tabular}


Table 2. Statistical mean \pm S.E.M. for IL-6 treated with each inhibitors.

\begin{tabular}{lllll}
\hline & IL-1 $\beta$ & $\mathrm{n}$ & $\mathrm{IL}-6$ & $\mathrm{n}$ \\
\hline Control & $35.6 \pm 4.0$ & 8 & $-21.4 \pm 2.5$ & 4 \\
SQ22536 & $30.0 \pm 3.6$ & 4 & $-21.4 \pm 1.3$ & 5 \\
GF109203 & $36.9 \pm 6.4$ & 4 & $-22.6 \pm 1.4$ & 5 \\
Staffic & $35.2 \pm 4.8$ & 4 & $-3.5 \pm 0.6$ & 5 \\
PD98059 & $7.5 \pm 1.1$ & 4 & $-4.0 \pm 0.9$ & 5 \\
\hline
\end{tabular}

\section{Results}

\subsection{IL-1 $\beta$ Facilitated $I_{B a}$}

Figure $1 \mathrm{a}$ and $\mathrm{b}$ shows that, in the presence of high external $\mathrm{Ba}^{2+}, 5 \mathrm{nM}$ IL-1 $\beta$ facilitated $\mathrm{I}_{\mathrm{Ba}}$ as shown with raw current traces obtained at $+10 \mathrm{mV}$ from $-80 \mathrm{mV}$ in the absence and presence of IL-1 $\beta$. $\mathrm{I}_{\mathrm{Ba}}$ was evoked every $5 \mathrm{~s}$ with a $100 \mathrm{~ms}$ depolarizing voltage step to $-10 \mathrm{mV}$ from a holding potential of $-80 \mathrm{mV}$. As shown in Figure 1a, application of $5 \mathrm{nM} \mathrm{IL-1} \beta$ facilitated $\mathrm{I}_{\mathrm{Ba}}$ from $-161 \mathrm{pA}$ to $-225 \mathrm{pA}$ (39.7\% facilitation) in this cell.

To investigate the voltage dependency of facilitation of $\mathrm{I}_{\mathrm{Ba}}$ by IL-1 $\beta$, we analyzed the current-voltage relations in the absence and presence of IL-1 $\beta$. The current-voltage relations measured before and during application of IL-1 $\beta$ are shown in Figure 1c. From a holding potential of $-80 \mathrm{mV}, \mathrm{I}_{\mathrm{Ba}}$ was activated with a peak current amplitude at $0 \mathrm{mV}$. IL-1 $\beta$ did not alter the current-voltage relationship. These results suggest that $5 \mathrm{nM} \mathrm{IL-1} \beta$ facilitated $\mathrm{I}_{\mathrm{Ba}}$ in MC3T3-E1 cells.

a

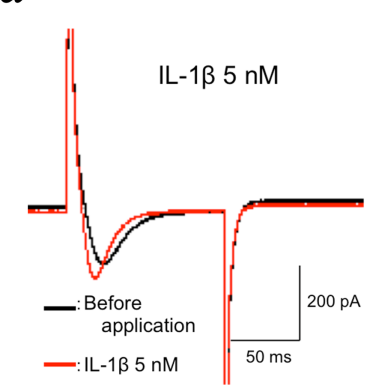

b

$\mathrm{c}$

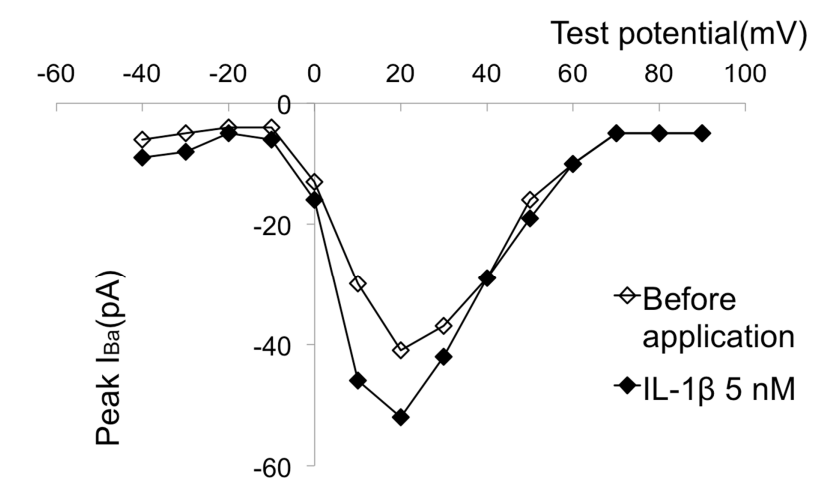

Figure 1. (a) Typical superimposed $\mathrm{I}_{\mathrm{Ba}}$ traces according to the time course graph $\mathrm{B}$. $\mathrm{I}_{\mathrm{Ba}}$ was evoked from a holding potential of $-80 \mathrm{mV}$ by a $100 \mathrm{msec}$ voltage step to $-10 \mathrm{mV}$ at $5 \mathrm{sec}$ intervals. (b) Typical time course of $5 \mathrm{nM}$ IL-1 $\beta$-induced facilitation of $\mathrm{I}_{\mathrm{Ba}}$. IL-1 $\beta(5 \mathrm{nM})$ was bath-applied during the times indicated by the filled bar. (c) Current-voltage relationship of $\mathrm{I}_{\mathrm{Ba}}$ evoked by a series of voltage steps from a holding potential of $-80 \mathrm{mV}$ to test potentials between -80 and $+40 \mathrm{mV}$ in $+10 \mathrm{mV}$ increments in the absence (opened circles) and presence

(filled circles) of $5 \mathrm{nM}$ IL-1 $\beta$ 


\subsection{IL-6 Facilitated $I_{B a}$}

Figure $2 \mathrm{a}$ and $\mathrm{b}$ shows that $5 \mathrm{nM}$ IL- 6 facilitated $\mathrm{I}_{\mathrm{Ba}}$ as shown with raw current traces obtained at $+10 \mathrm{mV}$ from $-80 \mathrm{mV}$ in the absence and presence of IL-6. $\mathrm{I}_{\mathrm{Ba}}$ was evoked every $5 \mathrm{~s}$ with a $100 \mathrm{~ms}$ depolarizing voltage step to $-10 \mathrm{mV}$ from a holding potential of $-80 \mathrm{mV}$. As shown in Figure 2A, application of $5 \mathrm{nM}$ IL-6 facilitated $\mathrm{I}_{\mathrm{Ba}}$ from $-75 \mathrm{pA}$ to $-103 \mathrm{pA}$ (37.3\% facilitation) in this cell.

To investigate the voltage dependency of facilitation of $\mathrm{I}_{\mathrm{Ba}}$ by $5 \mathrm{nM}$ IL-6, we analyzed the current-voltage relations in the absence and presence of $5 \mathrm{nM} \mathrm{IL-6}$. The current-voltage relations measured before and during application of $5 \mathrm{nM}$ IL-6 are shown in Figure 2c. From a holding potential of $-80 \mathrm{mV}, \mathrm{I}_{\mathrm{Ba}}$ was activated with a peak current amplitude at $20 \mathrm{mV}$. IL- 6 did not alter the current-voltage relationship. These results suggest that 5 nM IL-6 facilitated $\mathrm{I}_{\mathrm{Ba}}$ in MC3T3-E1 cells.
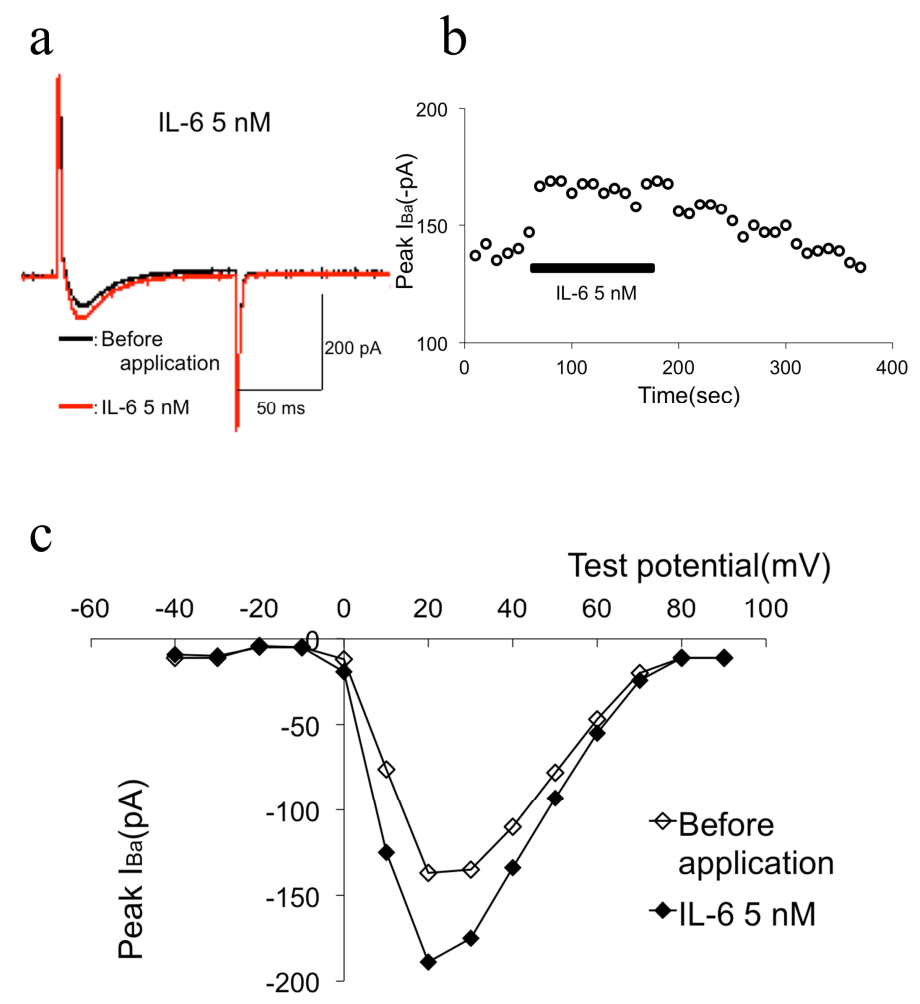

Figure 2. (a) Typical superimposed $I_{B a}$ traces according to the time course graph B. $I_{B a}$ was evoked from a holding potential of $-80 \mathrm{mV}$ by a $100 \mathrm{msec}$ voltage step to $-10 \mathrm{mV}$ at $5 \mathrm{sec}$ intervals. (b) Typical time course of $5 \mathrm{nM}$ IL-6-induced facilitation of $\mathrm{I}_{\mathrm{Ba}}$. IL-6 $(5 \mathrm{nM})$ was bath-applied during the times indicated by the filled bar. (c) Current-voltage relationship of $\mathrm{I}_{\mathrm{Ba}}$ evoked by a series of voltage steps from a holding potential of $-80 \mathrm{mV}$

to test potentials between -80 and $+40 \mathrm{mV}$ in $+10 \mathrm{mV}$ increments in the absence (opened circles) and presence (filled circles) of $5 \mathrm{nM} \mathrm{IL}-6$

\subsection{IL-6 Inhibited $I_{B a}$}

In addition to facilitation, IL-6-induced inhibition of $\mathrm{I}_{\mathrm{Ba}}$ could be observed. Figure $3 \mathrm{a}$ and $\mathrm{b}$ shows that $50 \mathrm{nM}$ IL-6 inhibited $\mathrm{I}_{\mathrm{Ba}}$ as shown with raw current traces obtained at $+10 \mathrm{mV}$ from $-80 \mathrm{mV}$ in the absence and presence of IL-6. $\mathrm{I}_{\mathrm{Ba}}$ was evoked every $5 \mathrm{~s}$ with a $100 \mathrm{~ms}$ depolarizing voltage step to $-10 \mathrm{mV}$ from a holding potential of $-80 \mathrm{mV}$. As shown in Figure 3a, application of $50 \mathrm{nM}$ IL-6 inhibited $\mathrm{I}_{\mathrm{Ba}}$ from $-328 \mathrm{pA}$ to -236 pA (28.0\% inhibition) in this cell.

To investigate the voltage dependency of facilitation of $\mathrm{I}_{\mathrm{Ba}}$ by $50 \mathrm{nM}$ IL-6, we analyzed the current-voltage relations in the absence and presence of $50 \mathrm{nM}$ IL-6. The current-voltage relations measured before and during application of $50 \mathrm{nM}$ IL-6 are shown in Figure 3c. From a holding potential of $-80 \mathrm{mV}, \mathrm{I}_{\mathrm{Ba}}$ was activated with a peak current amplitude at $20 \mathrm{mV}$. IL- 6 did not alter the current-voltage relationship. These results suggest that 50 nM IL-6 inhibited $\mathrm{I}_{\mathrm{Ba}}$ in MC3T3-E1 cells. 


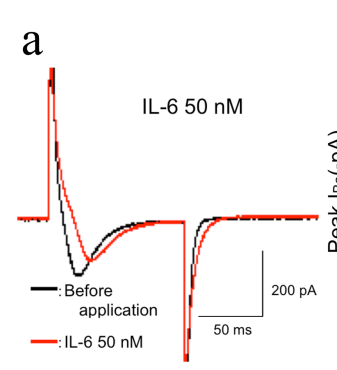

b

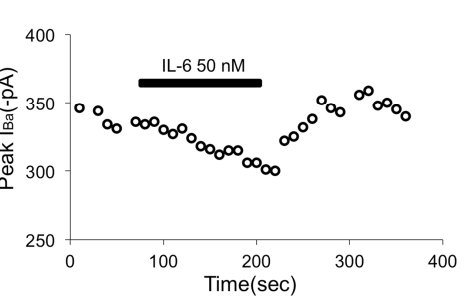

C

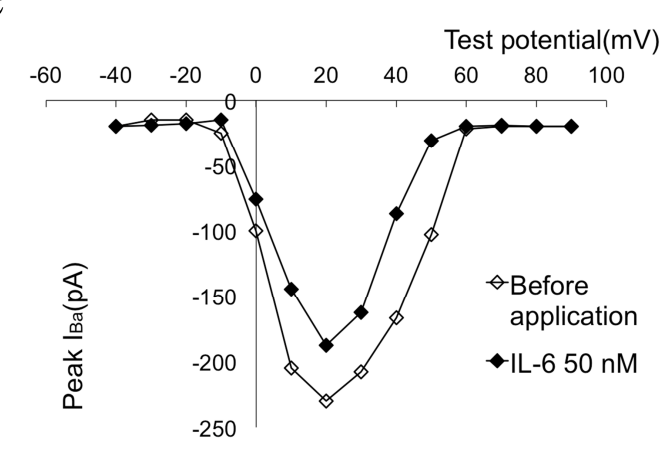

Figure 3. (a) Typical superimposed $I_{\mathrm{Ba}}$ traces according to the time course graph $\mathrm{B}$. $\mathrm{I}_{\mathrm{Ba}}$ was evoked from a holding potential of $-80 \mathrm{mV}$ by a $100 \mathrm{msec}$ voltage step to $-10 \mathrm{mV}$ at $5 \mathrm{sec}$ intervals. (b) Typical time course of $50 \mathrm{nM}$ IL-6-induced inhibition of $\mathrm{I}_{\mathrm{Ba}}$. IL-6 $(50 \mathrm{nM})$ was bath-applied during the times indicated by the filled bar. (c) Current-voltage relationship of $\mathrm{I}_{\mathrm{Ba}}$ evoked by a series of voltage steps from a holding potential of -80 $\mathrm{mV}$ to test potentials between -80 and $+40 \mathrm{mV}$ in $+10 \mathrm{mV}$ increments in the absence (opened circles) and presence (filled circles) of $50 \mathrm{nM}$ IL-6
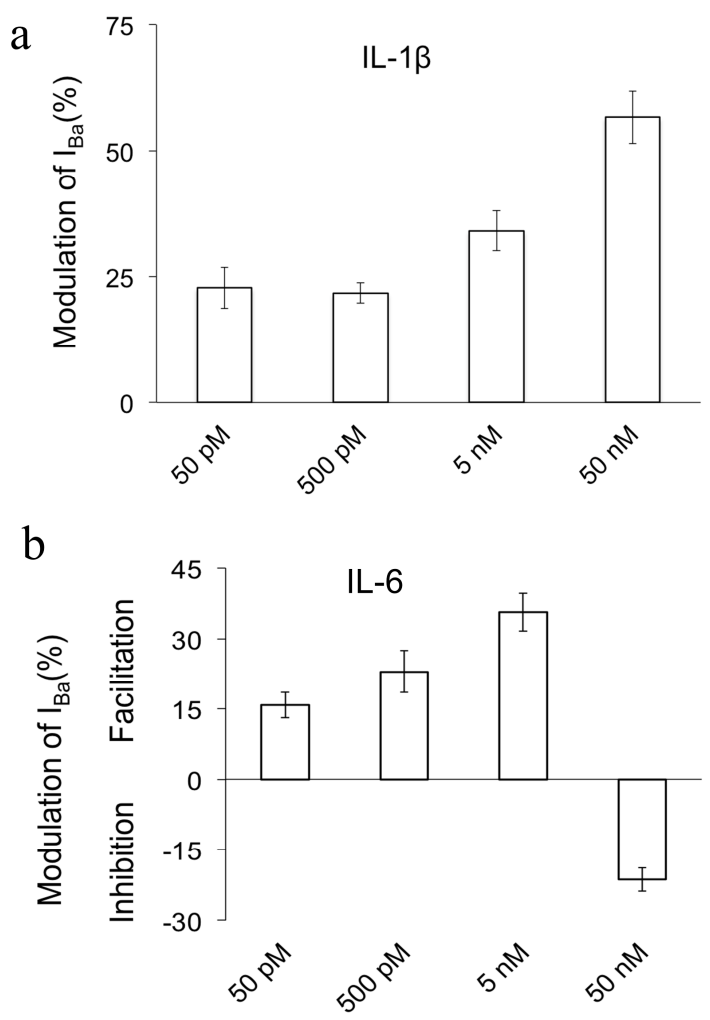

Figure 4. (a) Histogram demonstrating the degree of $\mathrm{I}_{\mathrm{Ba}}$ modulation by $50 \mathrm{pM}-50 \mathrm{nM}$ IL-1 $\beta$. (b) Histogram demonstrating the degree of $\mathrm{I}_{\mathrm{Ba}}$ modulation by 50 pM- $50 \mathrm{nM}$ IL-6 
a

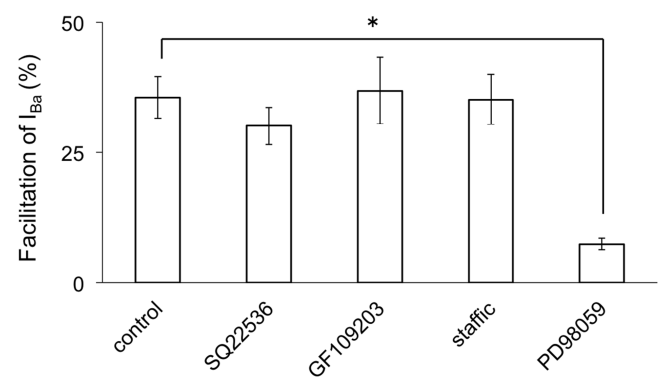

b

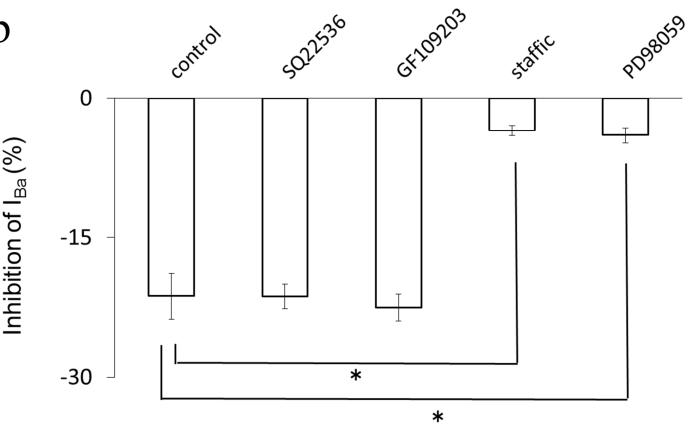

Figure 5. (a) Summary of IL-6-induced facilitation of $\mathrm{I}_{\mathrm{Ba}}$ under various conditions. Histogram demonstrating the degree of $\mathrm{I}_{\mathrm{Ba}}$ facilitation by $5 \mathrm{nM}$ IL-6 in control (untreated cells), after SQ22536 (an AC inhibitor), after GF109203 (a PKC inhibitor), after staffic (a STAT3 inhibitor), and PD98059 (a MAPK inhibitor). (b) Summary of IL-6-induced inhibition of $\mathrm{I}_{\mathrm{Ba}}$ under various conditions. Histogram demonstrating the degree of $\mathrm{I}_{\mathrm{Ba}}$ inhibition by $50 \mathrm{nM}$ IL-6 in control (untreated cells), after SQ22536 (an AC inhibitor), after GF109203 (a PKC inhibitor), after staffic (a STAT3 inhibitor), and PD98059 (a MAPK inhibitor). $*<0.05$ compared with control

\subsection{IL-1 $\beta$ and -6 Modulated $I_{B a}$ Depends On Concentration}

The concentration-response relationship in the IL- $1 \beta$ and -6-induced modulation of $\mathrm{I}_{\mathrm{Ba}}$ is shown in Figure $4 \mathrm{a}$ and b, respectively.

Application of 50 pM-50 nM IL-1 $\beta$ facilitated $\mathrm{I}_{\mathrm{Ba}}$. To generate a concentration-response curve, IL concentrations were applied randomly, and each MC3T3-E1 cells were exposed to only a single concentration. Figure 4a shows that progressive voltage-dependent facilitations in IL-1 $\beta$ concentrations resulted in a progressively greater facilitation of $\mathrm{I}_{\mathrm{Ba}}$.

In addition, application of 50 pM-5 nM IL- 6 facilitated $\mathrm{I}_{\mathrm{Ba}}$. In contrast to above results, $50 \mathrm{nM}$ IL-6 inhibited $\mathrm{I}_{\mathrm{Ba}}$ in MC3T3-E1 cells.

\subsection{Characterization of Second Messengers in $5 \mathrm{nM}$ IL-6-Induced Facilitation of $I_{B a}$}

To evaluate the possible contribution of adenylate cyclase (AC) to the IL-6-induced facilitation of $\mathrm{I}_{\mathrm{Ba}}$, the effects of IL-6 on $\mathrm{I}_{\mathrm{Ba}}$ in cells treated with SQ22536 (an AC inhibitor) were investigated. Treatment with SQ22536 (10 $\mu \mathrm{M}$ for $30 \mathrm{~min}$ ) did not attenuate the IL-6-induced facilitation of $\mathrm{I}_{\mathrm{Ba}}$.

To evaluate the possible contribution of protein kinase $\mathrm{C}$ (PKC) to the IL-6-induced facilitation of $\mathrm{I}_{\mathrm{Ba}}$, the effects of IL-6 on $\mathrm{I}_{\mathrm{Ba}}$ in cells treated with GF109203X (a selective PKC inhibitor) were investigated. Treatment with GF109203X (10 $\mu \mathrm{M}$ for $30 \mathrm{~min}$ ) did not attenuate the IL-6-induced facilitation of $\mathrm{I}_{\mathrm{Ba}}$.

To evaluate the possible contribution of STAT3 to the IL-6-induced facilitation of $\mathrm{I}_{\mathrm{Ba}}$, the effects of IL-6 on $\mathrm{I}_{\mathrm{Ba}}$ in cells treated with staffic (a selective signal transducers and activators of transcription 3, STAT3, inhibitor) were investigated. Treatment with staffic $(20 \mu \mathrm{M}$ for $2 \mathrm{~min})$ did not attenuate the IL-6-induced facilitation of $\mathrm{I}_{\mathrm{Ba}}$.

To evaluate the possible contribution of MAPK to the IL-6-induced facilitation of $\mathrm{I}_{\mathrm{Ba}}$, the effects of IL- 6 on $\mathrm{I}_{\mathrm{Ba}}$ in cells treated with PD98059 (a selective MAPK inhibitor) were investigated. Treatment with PD98059 (10 $\mu \mathrm{M}$ for $2 \mathrm{~min}$ ) attenuated the IL-6-induced facilitation of $\mathrm{I}_{\mathrm{Ba}}$.

These results suggest that IL-6 facilitates VDCCs involving MAPK pathways in MC3T3-E1 cells. 


\subsection{Characterization of Second Messengers in $50 \mathrm{nM}$ IL-6-Induced Inhibition of $I_{B a}$}

To evaluate the possible contribution of AC to the IL-6-induced inhibition of $\mathrm{I}_{\mathrm{Ba}}$, the effects of IL-6 on $\mathrm{I}_{\mathrm{Ba}}$ in cells treated with SQ22536 (an AC inhibitor) were investigated. Treatment with SQ22536 (10 $\mu \mathrm{M}$ for $30 \mathrm{~min}$ ) did not attenuate the IL-6-induced inhibition of $\mathrm{I}_{\mathrm{Ba}}$.

To evaluate the possible contribution of protein kinase $\mathrm{C}$ (PKC) to the IL-6-induced inhibition of $\mathrm{I}_{\mathrm{Ba}}$, the effects of IL-6 on $\mathrm{I}_{\mathrm{Ba}}$ in cells treated with GF109203X (a selective PKC inhibitor) were investigated. Treatment with GF109203X (10 $\mu \mathrm{M}$ for $30 \mathrm{~min}$ ) did not attenuate the IL-6-induced inhibition of $\mathrm{I}_{\mathrm{Ba}}$.

To evaluate the possible contribution of STAT3 to the IL-6-induced inhibition of $\mathrm{I}_{\mathrm{Ba}}$, the effects of IL- 6 on $\mathrm{I}_{\mathrm{Ba}}$ in cells treated with staffic (a selective STAT3 inhibitor) were investigated. Treatment with staffic $(20 \mu \mathrm{M}$ for 2 $\min$ ) attenuated the IL-6-induced inhibition of $\mathrm{I}_{\mathrm{Ba}}$.

To evaluate the possible contribution of MAPK to the IL-6-induced inhibition of $\mathrm{I}_{\mathrm{Ba}}$, the effects of IL-6 on $\mathrm{I}_{\mathrm{Ba}}$ in cells treated with PD98059 (a selective MAPK inhibitor) were investigated. Treatment with PD98059 (10 $\mu$ M for $2 \mathrm{~min}$ ) attenuated the IL-6-induced inhibition of $\mathrm{I}_{\mathrm{Ba}}$.

These results suggest that IL-6 inhibits VDCCs involving STAT3 and MAPK pathways in MC3T3-E1 cells.

\section{Discussion}

The present study investigated the effects of IL- $1 \beta$ and -6 on $\mathrm{I}_{\mathrm{Ba}}$ in MC3T3-E1 cells. Application of $50 \mathrm{pM}-50 \mathrm{nM}$ $\mathrm{IL}-1 \beta$ facilitated $\mathrm{I}_{\mathrm{Ba}}$. Application of $50 \mathrm{pM}-5 \mathrm{nM}$ IL-6 facilitated $\mathrm{I}_{\mathrm{Ba}}$ involving MAPK pathways. In contrast, $50 \mathrm{nM}$ IL-6 inhibited $\mathrm{I}_{\mathrm{Ba}}$ involving STAT3 and MAPK pathways in MC3T3-E1 cells. In this study, we used $50 \mathrm{pM}-50 \mathrm{nM}$ IL-1 $\beta$ and IL- 6 to modulate $\mathrm{I}_{\mathrm{Ba}}$. These IL concentrations are quite high. In normal state, serum IL- $1 \beta$ concentration is $0.9 \mathrm{pg} / \mathrm{ml}$ approximately (Chang et al., 2013). In the electrophysiological study and the immunocytochemistry study, however, several study demonstrated that high concentration, i.e. $0.57 \mathrm{nM}$ and $4.5 \mathrm{nM}$, of IL was used to modulate ion channel activity and protein expression in single neuron (Zhou et al., 2006; Islam et al., 2009). IL-1 $\beta$ and -6 were applied by perfusion pressure ejection from perfusion tubes with a tip diameter of $1 \mathrm{~mm}$ placed within $10 \mathrm{~mm}$ of the cell surface. Although the concentration of IL- $1 \beta$ and -6 actually seen by the cell is certainly lower than that contained in the stock solution, we applied the IL-1 $\beta$ and -6 using same perfusion system. We also observed that $\mathrm{I}_{\mathrm{Ba}}$ were recovered to values of peak $\mathrm{I}_{\mathrm{Ba}}$ after IL wash out using time course graph (Figures. 1b, 2b and $3 \mathrm{~b}$ ). Therefore, it can be considered that $50 \mathrm{pM}-50 \mathrm{nM} \mathrm{IL-} 1 \beta$ and IL-6 had no effect on the $\mathrm{I}_{\mathrm{Ba}}$.

In osteoblastic cells, several studies demonstrated that hormones modulated VSCCs, included in parathyroid hormone (PTH) (Green et al., 1991; Li et al., 1997; Yamaguchi et al., 1987), bradykinin (Tokuda et al., 1994), 1,25-dihydroxyvitamin $\mathrm{D}_{3}\left(1,25(\mathrm{OH})_{2} \mathrm{D}_{3}\right)$ (Bergh et al., 2006; Uchida et al., 2012; Zanello et al., 2006) and phalloidin, a stabilizer of actin filaments (Li et al., 2011). To our knowledge, the data presented here demonstrate for the first time that IL-1 $\beta$ and -6 modulates VSCCs in osteoblasts. In contrast to our results, Green et al. reported that IL- 6 did not alter basal intracellular $\mathrm{Ca}^{2+}$ concentration $\left(\left[\mathrm{Ca}^{2+}\right]_{\mathrm{i}}\right)$ but inhibited $\mathrm{Ca}^{2+}$ transient induced by PTH, prostaglandin $E_{2}$ and endothelin-1 in osteoblast (Green et al., 1994).

In this study, we have shown that $50 \mathrm{pM}-50 \mathrm{nM}$ IL-1 $\beta$ facilitated $\mathrm{I}_{\mathrm{Ba}}$. It has been demonstrated that local treatment with IL-1 $\beta(0.5 \mathrm{ng} / \mathrm{h})$ for $72 \mathrm{~h}$ resulted in increased osteoblasts concentration (Olmedo et al., 1999). Furthermore, reports of IL-1 $\beta$ promoting osteoblast proliferation during acute bone repair (Lange et al., 2009) and inducing differentiation of human mesenchymal stem cells into osteoblasts (Sonomoto et al., 2012). Increased DNA synthesis in response to IL-1 $\beta$ in vitro has been observed in osteoblast (Evans et al., 1989) and especially MC3T3-E1 cells (Ikeda et al., 1998). In contrast, however, it has been reported that IL-1 $\beta$ inhibits the stimulation of osteocalcin synthesis and has no influence on proliferation (Taichman et al., 1992). IL-1 $\beta$ also increases both osteoprotegerin protein release and mRNA levels (Hofbauer et al., 1998; Hofbauer et al., 1999). Recent study demonstrated that treatment with IL-1 $\beta$ resulted in biphasic effects on osteoblast differentiation. Short-term exposure ( 2 days) to IL- $1 \beta$ early in culture induces differentiation. Longer term exposure ( 6 days) to IL-1 $\beta$ inhibits osteoblast differentiation (Bellido et al., 1997).

In this study, we have shown that 50 pM-5 nM IL-6 facilitated $\mathrm{I}_{\mathrm{Ba}}$ involving MAPK pathways. In contrast, $50 \mathrm{nM}$ IL-6 inhibited $\mathrm{I}_{\mathrm{Ba}}$ involving STAT3 and MAPK pathways. What is the physiological relevance of IL-6-induced dual modulation of VSCCs, i.e. both facilitation and inhibition? Several studies indicated that IL-6 enhanced in vitro differentiation on osteoblasts (Bellido et al., 1997; Bellido et al., 1998; Franchimont et al., 2005; Itoh et al., 2006; Liu et al., 2006; Wong et al., 2003). In contrast to above reports, other studies have shown an inhibitory effect of IL-6 on bone formation (Malaval et al., 2001; Malaval et al., 2005). It can be considered that such dual effects are depends on IL-6 receptor's intracellular signals transduction mechanisms. There are three major MAPK subgroups identified, including the extracellular signal-regulated kinases (ERK1/2), p38 MAPK and c-jun- $\mathrm{NH}_{2}$-terminal 
kinases (JNKs). The signal transduction induced by IL-6 is mediated by homo- or heterodimerization of the gp130 receptor, subsequent activation of JAK, and phosphorylation of STAT (Heinrich et al., 2003). It has been demonstrated that activation of STAT3 is necessary for osteoblast differentiation and bone formation induced by IL-6 (Itoh et al., 2006). On the other hand, PKC $\delta$ and ERK1/2 are implicated in IL-6's inhibitory effect on bone formation (Chipoy et al., 2004). STAT3 plays multiple roles depending on the context or condition of cells. In some conditions, STAT3 is involved in growth arrest and differentiation, and even in cell death (Nakajima et al., 1996; Hirano et al., 1997; Hirano et al., 2000). In other conditions, STAT3 is involved in proliferation and cell survival (Hirano et al., 1997; Hirano et al., 2000). It is also possible that these dual effects depend on the conditions or differentiation stage of the osteoblast. IL-6 would stimulate the first stages of differentiation but on more mature cells, they would prevent further stimulation (Malaval et al., 2001; Malaval et al., 2005). Interestingly, VSCCs serve as growth of bone, regulate proliferation and differentiation, as mentioned above.

\section{References}

Bellido, T., Borba, V. Z., Roberson, P., \& Manolagas, S. C. (1997). Activation of the Janus kinase/STAT (signal transducer and activator of transcription) signal transduction pathway by interleukin-6-type cytokines promotes osteoblast differentiation. Endocrinology, 138, 3666-3676.

Bellido, T., O’Brien, C. A., Roberson, P. K., \& Manolagas, S. C. (1998). Transcriptional activation of the p21 (WAF1, CIP1, SDI1) gene by interleukin-6 type cytokines. A prerequisite for their pro-differentiating and anti-apoptotic effects on human osteoblastic cells. J Biol Chem, 273, 21137-21144. http://dx.doi.org/10. 1074/jbc.273.33.21137

Bergh, J. J., Shao, Y., Puente, E., Duncan, R. L., \& Farach-carson, M. C. (2006). Osteoblast $\mathrm{Ca}^{2+}$ permeability and voltage-sensitive $\mathrm{Ca}^{2+}$ channel expression is temporally regulated by 1,25-dihydroxyvitamin $\mathrm{D}_{3}$. $\mathrm{Am} J$ Physiol, 290, C822-C831. http://dx.doi.org/10.1152/ajpcell.00403.2005

Blanchard, F., Duplomb, L., Baud'huin, M., \& Brounais, B. (2009). The dual role of IL-6-type cytokines on bone remodeling and bone tumors. Cytokine Growth Factor Rev, 20, 19-28.

Chang, J. S., Chang, C. C., Chien, E. Y., Lin, S. S., Cheng-Shiuan, T., Bai, C. H., \& Chao, K. C. (2013). Association between interleukin $1 \beta$ and interleukin 10 concentrations: a cross-sectional study in young adolescents in Taiwan. BMC pediatrics, 13(1), 123. http://dx.doi.org/10.1186/1471-2431-13-123

Chipoy, C., Berreur, M., Couillaud, S., Pradal, G., Vallette, F., Colombeix, C., ... Blanchard, F. (2004). Downregulation of osteoblast markers and induction of the glial fibrillary acidic protein by oncostatin $\mathrm{M}$ in osteosarcoma cells require PKCdelta and STAT3. J Bone Miner Res, 19, 1850-1861. http://dx.doi.org/10. 1359/JBMR.040817

Dinarello, C. A. (1988). Biology of interleukin 1. FASEB J, 2, 108-115.

Dinarello, C. A. (1997). Interleukin-1. Cytokine Growth Factor Rev, 8, 253-265. http://dx.doi.org/10.1016/S1359 $-6101(97) 00023-3$

Duncan, R. L., Akanbi, K. A., \& Farach-Carson, M. C. (1998). Calcium signals and calcium channels in osteoblastic cells. Sem Nephrol, 18, 178-190.

Duriez, J., Flautre, B., Blary, M. C., \& Hardouin, P. (1993). Effects of the calcium channel blocker nifedipine on epiphyseal growth plate and bone turnover: a study in rabbit. Calcif Tissue Int, 52, 120-124. http://dx.doi.org/10.1007/BF00308320

Evans, D. B, Bunning, R. A., Van Damme, J., \& Russell, R. G. (1989). Natural human IL-1 beta exhibits regulatory actions on human bone-derived cells in vitro. Biochem Biophys Res Commun, 159, 1242-1248. http://dx.doi.org/10.1016/0006-291X(89)92243-2

Fang, M. A., \& Hahn, T. J. (1991). Effects of interleukin-6 on cellular function in UMR-106-01osteoblast like cells. J Bone Miner Res, 6, 133-139. http://dx.doi.org/10.1002/jbmr.5650060206

Franchimont, N., Wertz, S., \& Malaise, M. (2005). Interleukin-6: an osteotropic factor influencing bone formation? Bone, 37, 601-606. http://dx.doi.org/10.1016/j.bone.2005.06.002

Green, J., Kleeman, C. R., Schotland, S., \& Chaimovitz, C. (1991). Acute phosphate depletion dissociates hormonal stimulated second messengers in osteoblast-like cells. Endocrinology, 129, 848-858. http://dx.doi.org/10.1210/endo-129-2-848

Green, J., Schotland, S., Sella, Z., \& Kleeman, C. R. (1994). Interleukin-6 attenuates agonist-mediated calcium mobilization in murine osteoblastic cells. J Clin Invest, 93, 2340-2350. http://dx.doi.org/10.1172/JCI117239 
Hamill, O. P., Marty, A., Neher, E., Sakmann, B., \& Sigworth, F. J. (1981). Improved patch-clamp techniques for high-resolution current recording from cells and cell-free membrane patches. Pflugers Arch, 391, 85-100. http://dx.doi.org/10.1007/BF00656997

Heinrich, P. C., Behrmann, I., Haan, S., Hermanns, H. M., Muller-Newen, G., \& Schaper, F. (2003). Principles of interleukin (IL)-6-type cytokine signalling and its regulation. Biochem J, 374, 1-20. http://dx.doi.org/10. 1042/BJ20030407

Hirano, T., Ishihara, K., \& Hibi, M. (2000). Role of STAT3 in mediating the cell growth, differentiation and survival signals related through the IL-6 family of cytokine receptors. Oncogene, 19, 2548-2556. http://dx.doi.org/10.1038/sj.onc.1203551

Hirano, T., Nakajima, K., \& Hibi, M. (1997). Signaling mechanisms through gp130; a model of the cytokine system. Cytokine Growth Factor Rev, 8, 241-252. http://dx.doi.org/10.1016/S1359-6101(98)80005-1

Hofbauer, L. C., Dunstan, C. R., Spelsberg, T. C., Riggs, B. L., \& Khosla, S. (1998). Osteoprotegerin production by human osteoblast lineage cells is stimulated by vitamin D. bone morphogenetic protein-2, and cytokines. Biochem Biophys Res Commun, 250, 776-781. http://dx.doi.org/10.1006/bbrc.1998.9394

Hofbauer, L. C., Lacey, D. L., Dunstan, C. R., Spelsberg, T. C., Riggs, B. L., \& Khosla, S. (1999). Interleukin-1beta and tumor necrosis factor-alpha, but not interleukin-6, stimulate osteoprotegerin ligand gene expression in human osteoblastic cells. Bone, 25, 255-259. http://dx.doi.org/10.1016/S8756-3282 (99)00162-3

Hughes, F. J., \& Howells, G. L. (1993). Interleukin-6 inhibits bone formation in vitro. Bone Miner, 21, 21-28. http://dx.doi.org/10.1016/S0169-6009(08)80117-1

Ikeda, E., Kusaka, M., Hakeda, Y., Yokota, K., Kumegawa, M., \& Yamamoto, S. (1998). Effect of interleukin 1 beta on osteoblastic clone MC3T3-E1 cells. Calcif Tiss Int, 43, 162-166. http://dx.doi.org/10.1007/BF02571314

Ishimi, Y., Miyaura, C., Jin, C. H., Akasu, T., Abe, E., Nakamura, Y., ... Suda, T. (1990). IL-6 is produced by osteoblastsand induces bone resorption. J Immunol, 145, 3297-3303.

Islam, O., Gong, X., Rose-John, S., \& Heese, K. (2009). Interleukin-6 and neural stem cells: more than gliogenesis. Mol Biol Cell, 20, 188-99. http://dx.doi.org/10.1091/mbc.E08-05-0463

Itoh, S., Udagawa, N., Takahashi, N., Yoshitake, F., Narita, H., Ebisu, S., \& Ishihara, K. (2006). A critical role for interleukin-6 family-mediated Stat 3 activation in osteoblast differentation and bone formation. Bone, 39, 505-512. http://dx.doi.org/10.1016/j.bone.2006.02.074

Lange, J., Sapozhnikova, A., Lu, C., Hu, D., Li, X., Miclau, T. 3rd, \& Marcucio, R. S. (2010). Action of IL-1beta during fracture healing. J Orthop Res., 28, 778-84.

Li, F., Wang, W., Gu, M., Gyoneva, S., Zhang, J., Huang, S., ... Zhang, X. (2011). L-type calcium channel activity in osteoblast cells is regulated by the actin cytoskeleton independent of protein trafficking. $J$ Bone Miner Metab, 29, 515-525. http://dx.doi.org/10.1007/s00774-010-0252-6

Li, W., Duncan, R. L., Karin, N. J., \& Farach-Carson, M. C. (1997). 1,25 (OH $)_{2} \mathrm{D}_{3}$ enhances PTH-induced Ca ${ }^{2+}$ transients in preosteoblasts by activating L-type $\mathrm{Ca}^{2+}$ channels. Am J Physiol, 273, E599-E605.

Lin, F. H., Chang, J. B., McGuire, M. H., Yee, J. A., \& Brigman, B. E. (2010). Biphasic effects of Interleukin-1 $\beta$ on osteoblast differentiation in vitro. J Orthop Res, 28, 958-964.

Liu, X. H., Kirschenbaum, A., Yao, S., \& Levine, A. C. (2006). The role of the interleukin-6/gp130 signaling pathway in bone metabolism. Vitam Horm, 74, 341-355. http://dx.doi.org/10.1016/S0083-6729(06)74014-6

Loza, J., Stephan, E., Dolce, C., Dziak, R., \& Simasko, S. (1994). Calcium currents in osteoblastic cells: dependence upon cellular growth stage. Calcif Tissue Int, 55, 128-133. http://dx.doi.org/10.1007/BF00297188

Ma, S. H., Li, B., Huang, H. W., Peng, Y. P., \& Qiu, Y. H. (2012). Interleukin-6 inhibits L-type calcium channel activity of cultured cerebellar granule neurons. J Physiol Sci, 62, 385-392. http://dx.doi.org/10.1007/s12576 $-012-0215-x$

Malaval, L., \& Aubin, J. E. (2001). Biphasic effects of leukemia inhibitory factor on osteoblastic differentiation. J Cell Biochem, 81, 63-70. http://dx.doi.org/10.1002/jcb.1086

Malaval, L., Liu, F., Vernallis, A. B., \& Aubin, J. E. (2005). GP130/OSMR is the only LIF/IL-6 family receptor complex to promote osteoblast differentiation of calvaria progenitors. J Cell Physiol, 204, 585-593. http://dx.doi.org/10.1002/jcp.20312 
McDonald, F. (2004). Ion channels in osteoblasts: A story of two intracellular organelles. Surg J R Coll Surg Edinb Irel, 2, 63-69.

Miller, R. J. (1987). Multiple calcium channels and neuronal function. Science, 235, 46-52. http://dx.doi.org/10. $1126 /$ science. 2432656

Murphy, T. H., Worley, P. H., \& Baraban, J. M. (1991). L-type voltage-sensitive calcium channels mediate synaptic activation of immediate early genes. Neuron, 7, 625-635. http://dx.doi.org/10.1016/0896-6273 (91)90375-A

Nakajima, K., Yamanaka, Y., Nakae, K., Kojima, H., Ichiba, M., Kiuchi, N., ... Hirano, T. (1996). A central role for Stat 3 in IL-6-induced regulation of growth and differentiation in M1 leukemia cells. EMBO J, 15, 3651-3658.

Olmedo, M. L., Landry, P. S., Sadasivan, K. K., Albright, J. A., Meek, W. D., Routh, R., \& Marino, A. A. (1999). Regulation of osteoblast levels during bone healing. J Orthop Trauma, 13, 356-362. http://dx.doi.org/10.1097/00005131-199906000-00006

Reuter, H. (1983). Calcium channel modulation by neurotransmitters, enzymes and drugs. Nature, 301, 569-574. http://dx.doi.org/10.1038/301569a0

Shen, V., Cheng, S-L., Kohler, N. G., \& Peck, W. A. (1990). Characterization and hormonal modulation of IL-1 binding in neonatal mouse osteoblast like cells. J Bone Miner Res, 5, 507-515. http://dx.doi.org/10.1002/ jbmr.5650050513

Sonomoto, K., Yamaoka, K., Oshita, K., Fukuyo, S., Zhang, X., Nakano, K., ... Tanaka, Y. (2012). Interleukin-1 $\beta$ induces differentiation of human mesenchymal stem cells into osteoblasts via the Wnt-5a/receptor tyrosine kinase-like orphan receptor 2 pathway. Arthritis Rheum, 64, 3355-63. http://dx.doi.org/10.1002/art.34555

Stylianou, E., \& Saklatvala, J. (1998). Interleukin-1. Int J Biochem Cell Biol, 30, 1075-1079. http://dx.doi.org/10.1016/S1357-2725(98)00081-8

Taichman, R. S., \& Hauschka, P. V. (1992). Effects of interleukin-1 beta and tumor necrosis factor-alpha on osteoblastic expression of osteocalcin and mineralized extracellular matrix in vitro. Inflammation, 16, 587-601. http://dx.doi.org/10.1007/BF00919342

Tokuda, H., Kotoyori, J., Oiso, Y., \& Kozawa, O. (1994). Intracellular signaling mechanism of bradykinin in osteoblast-like cells: comparison with prostaglandin E2. Endocrinol J, 4, 189-195.

Uchida, Y., Endoh, T., Tazaki, M., \& Sueishi, K. (2012). Chronic bradykinin treatment alters 1 $\alpha, 25$-dihydroxyvitamin D3-induced calcium current modulation in pre-osteoblasts. Cell Calcium, 51, 383-392. http://dx.doi.org/10.1016/j.ceca.2011.12.014

Wen, L., Wang, Y., Wang, H., Kong, L., Zhang, L., Chen, X., \& Ding, Y. (2012). L-type calcium channels play a crucial role in the proliferation and osteogenic differentiation of bone marrow mesenchymal stem cells. Biochem Biophys Res Commun, 424, 439-445. http://dx.doi.org/10.1016/j.bbrc.2012.06.128

Wong, P. K., Campbell, I. K., Egan, P. J., Ernst, M., \& Wicks, I. P. (2003). The role of the interleukin-6 family of cytokines in inflammatory arthritis and bone turnover. Arthritis Rheum, 48, 1177-1189. http://dx.doi.org/10. 1002/art.10943

Yamaguchi, D. T., Hahn, T. J., Iida-Klein, A., Kleeman, C. R., \& Muallem, S. (1987). Parathyroid hormone-activated calcium channels in an osteoblast-like clonal osteosarcoma cell line. cAMP-dependent and cAMP-independent calcium channels. J Biol Chem, 262, 7711-7718.

Zanello, L. P., \& Norman, A. (2006). $1 \alpha, 25(\mathrm{OH}) 2$ vitamin D3 actions on ion channels in osteoblasts. Steroids, 71, 291-297. http://dx.doi.org/10.1016/j.steroids.2005.09.012

Zhou, C., Ye, H. H., Wang, S. Q., \& Chai, Z. (2006). Interleukin-1 $\beta$ regulation of N-type Ca2+ channels in cortical neurons. Neurosci Lett, 403, 181-185. http://dx.doi.org/10.1016/j.neulet.2006.04.043

\section{Copyrights}

Copyright for this article is retained by the author(s), with first publication rights granted to the journal.

This is an open-access article distributed under the terms and conditions of the Creative Commons Attribution license (http://creativecommons.org/licenses/by/3.0/). 